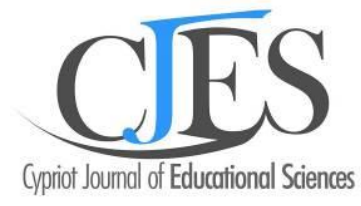

$\underline{\text { www.cjes.eu }}$

\title{
Communication skills and its role in decreasing tension in online learning during covid 19 pandemic: Case study of public schools
}

Omar Soud AlKhamaiseh a *, Al-Balqa Applied Universit, Salt, and 00962, Jordan https://orcid.org/0000-0003$\underline{2914-6647}$

\section{Suggested Citation:}

AlKhamaiseha, O. S. (2022). Communication skills and its role in decreasing tension in online learning during covid 19 pandemic: Case study of public schools. Cypriot Journal of Educational Science. 17(2), 357-371. https://doi.org/10.18844/cjes.v17i2.6812

Received from August 03, 2021; revised from August 14, 2021, accepted from February 12, 2022

${ }^{0} 2022$ Birlesik Dunya Yenilik Arastirma ve Yayincilik Merkezi. All rights reserved.

\begin{abstract}
This study aimed to uncover communication skills and their role in decreasing tension in online learning during Covid 19 pandemic. A descriptive-analytical method was used. The study sample consisted of (375) teachers in Amman. The results showed that the degree of communication skills of teachers during the COVID-19 pandemic in public schools was moderate. Furthermore, the degree of students' tension in online learning was moderate as well. The study recommended the necessity of using new methods and innovative teaching methods to improve students 'communication skills, such as using games and getting support from parents to reduce tension in online learning. This study contributes to shedding light on the need to improve students' communication skills during the Corona pandemic and the ensuing closure in schools and the adoption of distance learning to reduce stress and anxiety about failure, the decline in the academic level and failure to achieve high achievements.
\end{abstract}

Keywords: Communication Skills, Tension, Online Learning, COVID 19 Pandemic, Public Schools.

\footnotetext{
* ADDRESS FOR CORRESPONDENCE: Omar Soud AlKhamaiseh, Al-Balqa Applied Universit, Salt, and 00962, Jordan E-mail address: dr-omarsoud@bau.edu.jo / Tel.: +9627 77942073
} 


\section{Introduction}

Communication is a social necessity by human nature inclined to interact and work within the framework of the daily life that the individual lives (Haider \& Burfat, 2018). It includes exchanging experiences and ideas daily to solve the problems that arise due to work conditions and daily complexities. In the twenty-first century, there is a need to use diverse communication skills in all areas of life to enhance the way messages are structured, sent and received (Ndidi \& Alike, 2018).

Communication is considered a vital asset in education. According to (Ansari et al., 2017), good communication skills play a great role in improving the cognitive perception of the students. In other words, communication skills help students to express themselves freely by sharing ideas with others. This may help to create a positive atmosphere in the learning environment (Chung, Yoo, Kim, Lee \& Zeidler, 2016) whether it is verbal or nonverbal communication; both have equal importance. However, the most common method of communication is the verbal method using an exact language where it is a two-way procedure, with feedback on the message received. Separately from oral communication, information and data can also be exchanged using symbols or signs (Ogbo, Obiekwe \& Emere, 2020).

Syaiful, Muslim, Huda, Mukminin \& Habibi (2019) believe that communication between teacher and student is an essential key to excellent distance education provided to all participants in order to meet their needs. Manafa (2019) adds that in traditional education, the process of communication between the recipient and the dispatcher of students and teachers is usually done easily. However, distance education has become a more effective way to improve communication skills between teachers and students. During Covid-19 pandemic, distance education has spread more widely around the world. This method has been used so that students can complete their education smoothly (Mahmut, 2020).

Nowadays, distance education is an innovative educational structure that contains a high degree of flexibility and provides options to control time, place and pace of education for students (Simonson, Zvacek \& Smaldino, 2019). Nevertheless, this does not mean that it is free of problems. Students feeling anxious and stressed due to not being able to adapt to this new system is among the required barriers that affect successful distance learning and education (Kwaah \& Essilfie, 2017).

Extreme stress among students leads to poor academic performance, school dropout, addiction, crime, etc. Additionally, (Lawless \& Allan, 2003) argues that high levels of stress not only lead to anxiety and poor performance, but may also lead to an increased incidence of errors and inappropriate behaviour such as screening fraud and neglect.

Hence, good communication may play a vital role in increasing the stress and anxiety among students during online education processes (Saadé, Kira, Mak, \& Nebebe, 2017). As a result of the importance of developing the communication skills between teachers and students to decrease the stress in online learning during COVID 19 pandemic, the educational conference conducted by the Ministry of Education recommended the necessity of enhancing the role of e-learning in schools, and improving communication skills between teachers and students to advance and improve the educational process. Therefore, the researcher finds it necessary to identify communication skills and their role in decreasing tension in online learning during Covid -19 pandemic in the public schools.

The challenge facing students now is to get their education in the right way and to ensure that they are enriched in their cognitive and behavioural structure. The spread of the Coronavirus and the closure of schools and universities contributed to the spread of panic and anxiety among students and 
their parents. In addition, the emergence of the idea of distance education and its application among students overnight increased this panic and tension between them.

The researcher noticed, under the nature of his work as a professor in universities and his familiarity with many studies, that the levels of anxiety and tension among students were high due to the reliance on the process of distance education in schools. Another challenge that students face is the weak ability of their parents to provide portable devices to all children and the lack of the possibility of continuous communication with the teacher whom they took directions and instructions directly from, which affected students' achievement, and reduced their level of achievement. Therefore, this study came to identify the communication skills and their role in decreasing tension in online learning during COVID 19 pandemic

\subsection{Questions of the study}

Question 1: 'What is the degree of communication skills of teachers during the COVID 19 pandemic in public schools?'

Question 2: 'What is the degree of students' tension in online learning during COVID 19 pandemic in public schools?'

Question 3: Is there a relationship between Communication Skills and Tension in Online Learning during the COVID-19 Pandemic?

\subsection{Procedural definitions of the terms}

- Communication Skills: A set of skills that a person uses in his daily life to transfer ideas and information to the people and parties around him, as this skill helps to communicate information correctly and understandably by the other party. They can either be verbal, gesture, or written skills. This information must reach the other party correctly for it to be answered appropriately by them (Gartmeier et al., 2015).

- Tension: A person's feelings about a challenging or threatening situation or action. The reason for these internal feelings is due to external pressures or emergency changes that may occur in the daily routine of actions (Alkan, 2013).

- Online learning: one of the modern learning methods that depend mainly on giving lectures from the virtual classroom. Students receive the lecture while they are at home, in their clubs, cities, or anywhere in the world (Chick et al, 2020).

- COVID 19 pandemic: a large group of viruses that can cause a range of diseases, ranging from a common cold to severe acute respiratory syndrome (SARS). The resulting disease is called Coronavirus 2019 (COVID-19) (Keeling, Hollingsworth \& Read, 2020).

\section{Theoretical Framework and Related Research}

\subsection{Communication Skills}

Communication is the ability to exchange messages between people verbally or nonverbally. Communication is used in the human contact to talk, argue, express opinions and thoughts, or even conduct daily conversations (Brink \& Costigan, 2015). According to Siddiq et al., (2016), communication with people aims to share and pass on their intentions to whoever addresses them. Erozkan (2013) states that the parties involved in the communication process in the school classroom are teachers and students, which mean that there is communication and interaction between the teacher and the student and students with each other. As part of the communication process, 
teachers try to express their feelings and thoughts to make positive adjustments in students' behaviours and attitudes. The fact that the communication process between the teacher and the student is done personally makes it easier and more efficient to make these behavioural modifications (Simsek \& Erdem, 2020).

The goal of communication is to share and cooperate meaning among the communicating individuals (Siddiq, Scherer \& Tondeur, 2016). Erozkan (2013) emphasizes that the process of communication in the classroom in the school environment occurs as teacher-student communication or studentstudent communication. A teacher shares his/her emotions and thoughts with the students to create a behavioural change and performs face to face interpersonal communication while contacting students and exchanging information with them (Simsek \& Erdem, 2020).

As in all aspects of life, communication plays an important role in education and training. Since the teaching process is a very communicative activity, it is important to use appropriate communication skills between teachers and students (Manafa, 2018). According to Ndidi \& Alike (2018), effective communication skills are the first requirement of a persuasive teaching process. For individuals to be able to express themselves, share their thoughts and emotions, and understand and build empathy for others, they need to train themselves to be good listeners and speakers (Remland, 2016).

According to Simonson, Zvacek \& Smaldino (2019), the educational environment requires the provision of a complex and interconnected network. To provide a healthy learning environment, effective communication bridges must be provided between students. Creating effective communication in the classroom environment depends on the teacher's ability to engage students in the classroom and push them to express their opinions and thoughts. Ogbo, Obiekwe \& Emere (2020) indicate that to improve educational communication, teachers are supposed to have a great deal of responsibility for engaging all parts of the educational process in curriculum presentation and interpretation.

Gulec \& Temel (2015) concluded that enhancing communication skills between teachers and students plays a fundamental role in improving the quality of teaching and learning, and increasing student interaction with the classroom. In this process, teachers must use not only verbal language but also nonverbal language. Educators are required to use these two techniques and employ them effectively to complete the educational process efficiently (Brink \& Costigan, 2015). Nonverbal communication is the process of communicating through sending and receiving messages without words between people. These messages may be sent through expressions, touch, body language, facial expressions, or eye contact. According to (Burgoon et al., 2016), individuals' body language includes movements, facial expressions, clothing, postures, and tones. Nonverbal communication conveys information about a variety of things, including their moods and situations at the time. Body language reveals information about what is happening inside a person. When people can read and use body language, they will be able to understand and interact with others more easily. Nonverbal communication is used to communicate our feelings, while verbal communication is used to convey information (Remland, 2016).

\subsection{Tension in Learning}

Stress is a method or mechanism for the body to respond to any kind of request or threat. When a person feels a threat - whether real or imagined - the body's defenses begin a rapid automatic process known as the "fight-or-flight" response or the "stress response". (Anderson \& Stevenson, 2019). 
In 1993, Richard Lazarus, a well-known psychologist believed that when events and obligations overwhelm one's ability to cope, tension occurs (Alkan, 2013). Whereas Hans Selye 1950 saw that stress is a non-specific response by the body to any pressure that the body is exposed to in order to adapt and respond to it whether in pleasure or pain. Moreover, as illustrated in the holistic medicine perspective, stress is described as physical exhaustion and a mentally or emotionally disturbing state that occurs in response to adverse external influences, and stress is defined as an individual-level response to excessive stress and trouble (Zaidi, Nadeem \& Gill, 2019).

Kwaah \& Essilfie (2017) argues that competition and academic loads cause stress in students during exams. Students do not suffer only from school-related issues, but family, environment and personal relationships affect them as well (Saadé et al., 2017). A qualitative measurement of stressors affecting students is usually studied to understand what affects students the most. Alkan (2013) believes that different stressors may affect students according to regional, cultural and environmental perspectives, making it an important issue to address in our region to be able to manage specific and significant stress factors.

\section{Online learning}

Many educational institutions are using online learning technology in their learning process. It has proved to have a significant impact on education (Mayende et al., 2017). Online learning was used in recent years very effectively in teaching to enhance the traditional forms of teaching and learning (Isman \& Dabaj, 2004).

Online learning has been defined as a learning environment that uses Information Communication Technology (ICT) to promote connection "between one learner and others learners, between learners and tutors, and between a learning community and its learning resources" (Allan \& Lawless, 2003).

Accessibility and flexibility are one of the main benefits of online learning. This means that it provides students with a learning experience that can be accessed at their most suitable time, can be customized to learners' style and needs and can be provided in short sections (Garthwait, 2014). Rayle (2011) emphasize that online learning can be flexible as it provides students with the opportunity to continue their education without the need to be concerned about the geographical location, time or place. In other words, travelling and meeting face to face is no longer needed to complete the education. It also allows them to work besides studying and have the opportunity to practice what they have learned in their current duties.

\section{Tension in Online Learning during COVID 19 Pandemic}

The COVID-19 pandemic is causing the largest chaos in education systems in history, affecting approximately 1.6 billion students in more than 190 countries and in all continents. The shutdown of schools and other educational institutions affected $94 \%$ of the world's students, and up to $99 \%$ in lowand lower-middle-income countries (Di Pietro, Biagi, Costa, Karpinski \& Mazza, 2020).

The distance learning process has spread out due to the rapid responses by governments around the world to ensure the continuity of education during the COVID-19 pandemic, including the Global Education Alliance sponsored by UNESCO (United Nations, 2020). Ensuring the permanency of learning during school closures has become a priority for governments around the world, many of which are turning to ICTs, requiring teachers to switch to delivering lessons online (Demuyakor, 2020). 
Although the distance-learning implementation is vital to ensuring continuousness of education after the closure of schools, students are likely, on average, to experience a loss of general skills and concepts during the closure (Hodges et al., 2020). Quite a few arguments can be provided forward to clarify this. First, there is evidence showing that isolated students spend less time learning compared to school opening time. Second, many students restricted where he/she lives due to COVID-19 may feel anxious and stressed and this may harmfully affect their capability to concentrate on schoolwork (Rehman et al., 2020). Third, the closure of the school and the lack of personal contact could make students less outwardly encouraged to involve in learning activities.

Students who are isolated at home due to COVID-19 may feel more tension and anxiety. Sprang \& Silman (2013) argues that students who were isolated during pandemic illnesses are more possible to encounter serious stress disorder, adjustment disorder, and grief. These negative psychological factors may have a detrimental effect on learning. These symptoms of stress may be comparable to those in the aftermath of hurricanes or earthquakes (Kuban \& Steele 2011).

\section{RESEARCH METHODOLOGY}

\subsection{The Research Method}

The current research is based on the quantitative approach as it fits the purpose of the study. A quantitative approach is concerned with the gathering and examination of information in numeric shape from the chosen sample.

\subsection{Participants:}

The study sample consisted of a random sample of (375) public schools' teachers in Amman, as it is classified into its demographic characteristics in the tables below:

Table (1): Demographic characteristics for the study sample (Gender)

\begin{tabular}{cll}
\hline \multirow{2}{*}{ Gender } & Sample & \\
\cline { 2 - 3 } & Frequency & Percentage \\
\hline Male & 155 & 41.3 \\
Female & 220 & 58.7 \\
Total & 375 & $100 \%$ \\
\hline
\end{tabular}

Table (1) shows that the percentage of males from the sample was (41.3\%) meanwhile it was (58.7\%) for females

Table (2): Demographic Characteristics of the Sample (Academic Level)

\begin{tabular}{lll}
\hline Academic Level & Sample & \\
\cline { 2 - 3 } & Frequency & Percentage \% \\
\hline Bachelor's Degree & 327 & 87.2 \\
Master's Degree & 40 & 10.7 \\
Doctorate Degree & 8 & 2.1 \\
Total & 375 & 100.0 \\
\hline
\end{tabular}

For the variable (Academic Level), it seems that the (Bachelor's Degree) achieved (87.2\%), (Master's Degree) achieved (10.7\%), and (Doctorate Degree) achieved (2.1\%). 
Table (3): Demographic Characteristics of the Sample (Years of Experience)

\begin{tabular}{lll}
\hline \multirow{2}{*}{ Years of Experience } & Sample & \\
\cline { 2 - 3 } & Frequency & Percentage \% \\
\hline Less than 1 year & 20 & 5.3 \\
$1-3$ years & 181 & 48.3 \\
$3-5$ years & 153 & 40.8 \\
More than 5 years & 21 & 5.6 \\
Total & 375 & $100.0 \%$
\end{tabular}

For the variable (Years of Experience) it seems that the (Less than 1 year) rank achieved (5.3\%), and (1-3 years) rank achieved (48.3\%) and ( $3-5$ years) rank achieved $(40.8 \%)$ and finally (More than 5 years) rank achieved (5.6\%).

\subsection{Research model}

\section{Communication Skills}

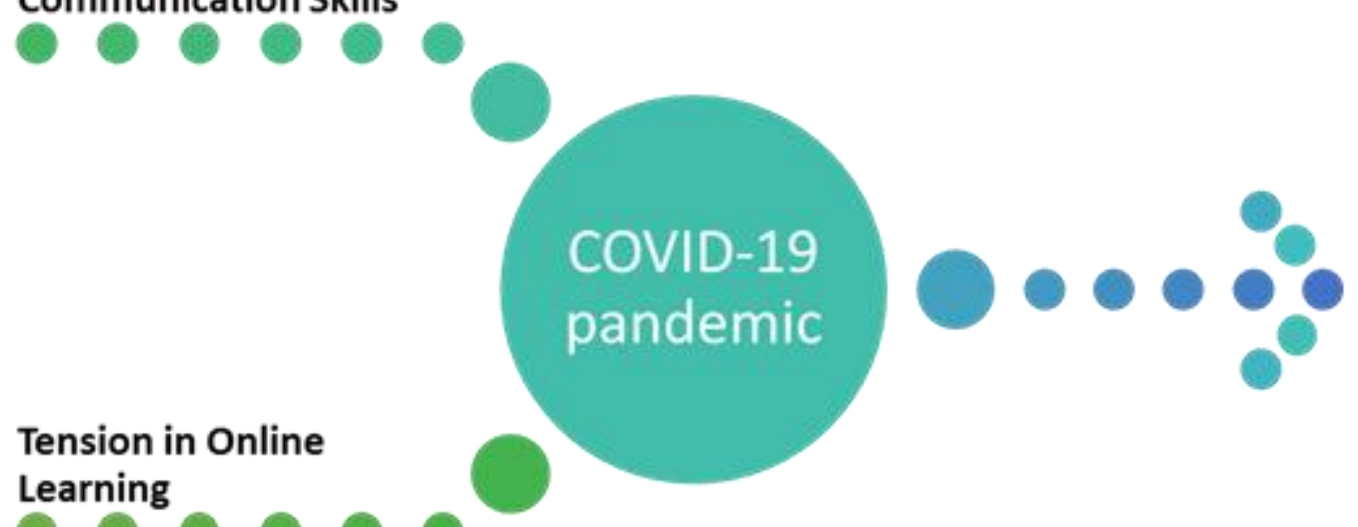

Figure 1. Research model

\subsection{Data Collection Tools}

The tool contains (20) questions measuring the communication skills and their role in decreasing tension in online learning during COVID-19 pandemic: Case Study of Public School. The questionnaires were distributed online.

The questionnaire contains (3) demographic variables and (20) questions represent study variables like the following:

Communication Skills Variable: it is formulated into benchmarks or objectives of (10) questions:

Tension in Online Learning Variable: it is formulated into benchmarks or objectives of (10) questions:

\subsection{Data Analysis and Interpretation}

To examine the questions used to examine communication skills and their role in decreasing tension in online learning during COVID-19 pandemic: Case Study of Public Schools, SPSS was used in dispensation of the following statistical techniques and tests during data analysis: 


\section{Reliability Test}

2. Frequencies and percentages

3. Descriptive Statistical Techniques

4. Pearson Correlation Test

For the study, means were divided into three stages, as (1.33) is the length of each stage:

- low: For means (1-2.33)

- Moderate: For means (2.34-3.67)

- High: For means (3.68-5)

\subsection{The validity of the instruments}

The test was given to experts to judge the extent to which the test was valid and reliable. For this reason, the test was designed to meet such requirements of the validity of the test. The experts were chosen according to their broad experiences in the field of teaching translation.

\subsection{Tool reliability}

To reach a degree of reliability of the test, the researcher used reliability testing of measuring instruments. The reliability of the scale highlights the consistency with which the instrument measures the concept and helps to assess the "quality" of the scale, for a comparison of students 'achievement of stability.

Table (4): Cronbach's alpha for the study fields

\begin{tabular}{llc}
\hline Field number & Field & Value \\
& & of $(\alpha)$ \\
\hline F1 & Communication Skills & 0.875 \\
F2 & Tension in Online Learning & 0.897 \\
\hline
\end{tabular}

As shown from the table above, the total Cronbach's alpha for the study fields was above $(0.60)$ which will lead to the stability of the results for this study.

\section{Study Results}

To analyze the data and examine the hypotheses in order to explore communication skills and their role in decreasing tension in online learning during COVID-19 pandemic: Case Study of public schools is used as it is shown as follow:

Question 1: 'What is the degree of communication skills of teachers during the COVID-19 pandemic in public schools?'

The arithmetic mean and standard deviation were calculated for each of the communication skills components. Table (5) shows the results: 
Table (5) :Descriptive Statistics for communication skills field

\begin{tabular}{|c|c|c|c|c|}
\hline $\begin{array}{l}\text { Question } \\
\text { number }\end{array}$ & Question & Mean & $\begin{array}{l}\text { Std. } \\
\text { Deviation }\end{array}$ & Rank \\
\hline 10 & $\begin{array}{l}\text { Students are involved in classroom discussion most of the } \\
\text { time. }\end{array}$ & 3.84 & 1.33 & 1 \\
\hline 8 & Students read what is written in clear language. & 3.67 & 1.16 & 2 \\
\hline 9 & $\begin{array}{l}\text { Students give importance to the body language while he/ } \\
\text { she speaks. }\end{array}$ & 3.64 & 1.17 & 3 \\
\hline 2 & $\begin{array}{l}\text { Students pay attention to the teacher's nonverbal cues } \\
\text { while listening: (signs, looks, body expressions, face and } \\
\text { eyes movement). }\end{array}$ & 3.63 & 1.18 & 4 \\
\hline 1 & Students listen carefully to teachers' speeches. & 3.57 & 1.12 & 5 \\
\hline 3 & $\begin{array}{l}\text { Students demonstrate a desire to listen by expressing } \\
\text { interest }\end{array}$ & 3.55 & 1.15 & 6 \\
\hline 4 & $\begin{array}{l}\text { Students listen fully and affirm that they understand what } \\
\text { I have said as a sign of respect to the speaker. }\end{array}$ & 3.46 & 1.09 & 7 \\
\hline 6 & $\begin{array}{l}\text { Students use expressions that have clear and precise } \\
\text { meanings in their writing style. }\end{array}$ & 3.43 & 1.09 & 8 \\
\hline 7 & $\begin{array}{l}\text { Students take into account the systematic sequence in the } \\
\text { paragraphs of the written material. }\end{array}$ & 3.41 & 1.14 & 9 \\
\hline \multirow[t]{2}{*}{5} & Students show enthusiasm in the conversation. & 3.22 & 1.16 & 10 \\
\hline & Communication skills & 3.52 & 1.05 & \\
\hline
\end{tabular}

Table (5) shows that the total mean for this field was (3.52) and with a standard deviation (1.05). We also noted that question (10) which states "Students are involved in the classroom discussion most of the time." ranked first with a mean of about (3.84) and a standard deviation of about (1.33) with a moderate level of response and question (5) which states "Students show enthusiasm in the conversation." with a mean of about (3.22) and a standard deviation of about (1.16) ranked last. This may be attributed to the teachers' keenness to provide an educational environment that ensures the participation of students in it and enriching it with their opinions and ideas. This may also be attributed to teachers' efforts to abandon traditional methods of indoctrination and follow modern methods that call for making the student a partner in the educational process.

\section{Question 2: 'What is the degree of students' tension in online learning during COVID-19 pandemic in public schools?'}

Means and standard deviation were calculated for each item in the tension in online learning during COVID-19 pandemic in public schools field. Table (6) shows the results: 
Table (6) :Descriptive Statistics for tension in online learning during COVID-19 pandemic in public schools field

\begin{tabular}{|c|c|c|c|c|}
\hline $\begin{array}{l}\text { Question } \\
\text { number }\end{array}$ & Question & Mean & $\begin{array}{l}\text { Std. } \\
\text { Deviation }\end{array}$ & Rank \\
\hline 15 & $\begin{array}{l}\text { Students are distracted during the class, which } \\
\text { makes them afraid of not acquiring the } \\
\text { information. }\end{array}$ & 3.54 & 1.53 & 1 \\
\hline 14 & $\begin{array}{l}\text { The student feels panicked when he/ she fails to } \\
\text { use distance education tools. }\end{array}$ & 3.42 & 1.45 & 2 \\
\hline 20 & $\begin{array}{l}\text { Students feel nervous about unfamiliarity with } \\
\text { online courses. }\end{array}$ & 3.38 & 1.48 & 3 \\
\hline 18 & $\begin{array}{l}\text { Students feel that distance education reduces } \\
\text { their ability to express their ideas. }\end{array}$ & 3.35 & 1.44 & 4 \\
\hline 13 & $\begin{array}{l}\text { Students feel very nervous when they take an } \\
\text { important test online. }\end{array}$ & 3.34 & 1.42 & 5 \\
\hline 19 & $\begin{array}{l}\text { Students feel nervous about having to rely on } \\
\text { themselves in bringing and researching new } \\
\text { concepts online. }\end{array}$ & 3.32 & 1.45 & 6 \\
\hline 16 & $\begin{array}{l}\text { The momentum of information confuses the } \\
\text { student during distance education. }\end{array}$ & 3.3 & 1.39 & 7 \\
\hline 17 & $\begin{array}{l}\text { Students become anxious when they encounter } \\
\text { problems accessing online-computerized curricula. }\end{array}$ & 3.29 & 1.38 & 8 \\
\hline 12 & $\begin{array}{l}\text { During the exams, students feel confused when } \\
\text { the internet is disconnected. }\end{array}$ & 3.28 & 1.4 & 9 \\
\hline \multirow[t]{2}{*}{11} & $\begin{array}{l}\text { The student is concerned that he/she may not } \\
\text { have acquired all the knowledge necessary for his } \\
\text { future profession. }\end{array}$ & 3.14 & 1.34 & 10 \\
\hline & $\begin{array}{l}\text { Tension in online learning during COVID-19 } \\
\text { pandemic in public schools }\end{array}$ & 3.34 & 1.37 & \\
\hline
\end{tabular}

Table (6) illustrated the total mean for this field was (3.34) and with a standard deviation (1.37). We also noted that question (15) which states "students are distracted during the class, which makes them afraid of not acquiring the information." ranked first with a mean of (3.54) and standard deviation of (1.53) with a moderate level of response and question (11) which states "Student is concerned that he/she may not have acquired all the knowledge necessary for his future profession" with a mean of (3.14) and standard deviation of (1.34) came in the last rank. This may be attributed to the fact that when studying remotely, the student is exposed to many distractions that divert his/her attention from the class. These distractions may be from family members or friends and others, which makes him completely unreactive to what the teacher proposes in the lesson. 


\section{Question 3: Is there a relationship between Communication Skills and Tension in Online Learning during the COVID-19 Pandemic?}

To determine if there is any relation between communication skills and tension in online learning during covid-19 pandemic, Pearson Correlation Test was used to identify the strength of the relationship between two variables. The degree of relationship between any two variables comes between (+1 and -1$)$. The more the degree of correlation is close to 1 , it indicates a positive correlation, and the more the degree of correlation is close to -1 , it indicates a negative correlation. The relation is shown in Table (7):

Table (7): Pearson Correlations Coefficients for Communication Skills and Tension in Online Learning during COVID-19 Pandemic

\begin{tabular}{lll}
\hline & Coefficients & $\begin{array}{l}\text { Tension in Online } \\
\text { Learning }\end{array}$ \\
\hline Communication Skills & Pearson Correlation & $-.822^{* *}$ \\
& Sig. (2-tailed) & .000 \\
& $\mathrm{~N}$ & 375 \\
\hline
\end{tabular}

As shown in Table (7), there is a significant relationship between communication skills and tension in online learning during COVID-19 Pandemic. The value of Pearson Correlation and the sig-value was $(0.000)$ which is less than the significance level $(\alpha=0.05)$. The correlation $(-0.822)$ indicates a negative relation between communication skills and tension in online learning during COVID-19 Pandemic. This may indicate that the students 'possession of communication skills help them easily engage in the distance learning process and make them overcome the difficulties and obstacles that cause them anxiety and tension.

\section{Discussion, Conclusion and Recommendation}

\subsection{Discussion}

Communication skills are among the basic interaction skills in schools (Shalian, 2021; Toppo \& Philomina, 2021; Claro et al., 2018). Based on this hypothesis, this article presents empirical findings on the importance of teachers' communication skills and their interaction with students, especially during the COVID-19 pandemic and distance learning. First, the empirical results confirmed that teachers' communication skills came to a moderate degree. This may be attributed to the difficulty of reaching students through multimedia and achieving a targeted understanding of the fact that some students do not have computers or tablets that enable them to communicate with the teacher permanently. Coman et al. (2020) confirm that distance learning may reduce the serious interaction between teacher and student, and weaken students' assessment properly.

The results showed that the degree of students' tension in online learning during the COVID-19 pandemic in public schools was moderate. This may be due to the fact that schools suffer from a lack of capabilities that establish balanced psychological health for students, and its absence leads to a doubling of students' psychological problems. This may lead to an increase in students' anxiety, tension and internal conflicts. Therefore, they feel many psychological pressures due to the loss of educational motivation, and the low spirit of competition. Klapproth et al. (2020) concluded that more 
than half of all participating teachers spent more than four hours a day teaching remotely and experienced significantly more stress than teachers who spent less time per day on teaching activities.

\subsection{Conclusion}

The importance of communication skills is beginning to receive even more attention from different parties as the days go by, especially in schools, as they are considered one of the most important skills that must be acquired due to their vital role in enabling students to communicate their ideas and express them more freely without fear of failure when engaging in any of the new educational methods.

This study aimed to find out communication skills and their role in decreasing tension in online learning during COVID 19 Pandemic. The data from teachers revealed that students could be anxious about online learning. The data also showed that to reduce anxiety and tension, teachers emphasized the connection between improving communication skills along with learning and anxiety in online learning especially when they are exposed to severe pressure due to school closures and isolation at home because of the spread of Covid-19. Additionally, they suggested that when students use the communications skills properly, the anxiety would be reduced. Therefore, the results suggested adopting modern methods of education and leaving the traditional methods of indoctrination to enhance the enthusiasm of students, and push them to better engage in the distance education process.

On the other hand, the results indicated that even though teachers were aware that they had to resolve the tension problem in online learning, they used the same teaching strategies and styles for all students without improving their communication skills first. In other words, they did not use different teaching strategies and other communication skills for anxious students.

The results suggested that to reduce students' tensions in online learning during the COVID-19 Pandemic, teachers must use new and innovative teaching methods to improve students 'communication skills, such as using games and getting support from parents to reduce tension in online learning.

The findings of this study contribute to finding out the role of communication skills in overcoming and reducing tensions in online learning during the COVID-19 Pandemic. This study was performed depending on the quantitative research strategy by using a questionnaire. Another study can be done using different data collection tools. For example, interviews or focus groups can be more effective to get more specific data. Furthermore, a study examining the same topic by collecting data from different participants as students and parents can also provide product information, and help to build the ways of reducing tensions in online learning during the COVID-19 Pandemic based on views of both sides.

\subsection{Recommendation}

This study is important from practical and theoretical perspectives. The study is the first experimental research in the literature that searches in communication skills and its role in decreasing tension in online learning during COVID 19 Pandemic. This study can help teachers to improve their communication skills with their students to decrease the feeling of stress and anxiety of failing, decline in the academic level and failure to achieve high achievement. This study may also help students gaining broader experiences by examining external sources other than the school curriculum, which reduces their tension and anxiety associated with the spread of the Covid-19 pandemic. 


\section{References}

Alkan, V. (2013). Reducing Mathematics Anxiety: The Ways Implemented by Teachers at Primary Schools. Online Submission, 3(3),

795-807. https://citeseerx.ist.psu.edu/viewdoc/download?doi=10.1.1.1041.2982\&rep=rep1\&type=pdf.

Allan, J., \& Lawless, N. (2003). Stress caused by online collaboration in e-learning: a developing model. Education+ Training. https://psycnet.apa.org/doi/10.1108/00400910310508955.

Anderson, R. E., \& Stevenson, H. C. (2019). RECASTing racial stress and trauma: Theorizing the healing potential of racial socialization in families. American Psychologist, 74(1), 63. https://psycnet.apa.org/doi/10.1037/amp0000392.

Ansari, H., Mohammadpoorasl, A., Shahedifar, N., Sahebihagh, M. H., Fakhari, A., \& Hajizadeh, M. (2017). Internet Addiction and interpersonal communication skills among high school students in Tabriz, Iran. Iranian Journal of Psychiatry and Behavioral Sciences, 11(2), 6. https://dx.doi.org/10.5812/ijpbs.4778

Brink, K. E., \& Costigan, R. D. (2015). Oral communication skills: Are the priorities of the workplace and AACSBaccredited business programs aligned?. Academy of Management Learning \& Education, 14(2), $205-221$. https://psycnet.apa.org/doi/10.5465/amle.2013.0044.

Burgoon, J. K., Guerrero, L. K., \& Manusov, V. (2016). Nonverbal communication. Routledge.

Chung, Y., Yoo, J., Kim, S. W., Lee, H., \& Zeidler, D. L. (2016). Enhancing Students'communication Skills In The Science Classroom Through Socioscientific Issues. International Journal of Science and Mathematics Education, 14(1),

1-27. https://www.academia.edu/7426217/Enhancing students communication skills in the science classroo $\mathrm{m}$ through socioscientific issues.

Claro, M., Salinas, Á., Cabello-Hutt, T., San Martín, E., Preiss, D. D., Valenzuela, S., \& Jara, I. (2018). Teaching in a Digital Environment (TIDE): Defining and measuring teachers' capacity to develop students' digital information and communication skills. Computers \& Education, 121, 162-174. https://doi.org/10.1016/i.compedu.2018.03.001.

Coman, C., Țîru, L. G., Meseșan-Schmitz, L., Stanciu, C., \& Bularca, M. C. (2020). Online teaching and learning in higher education during the coronavirus pandemic: students' perspective. Sustainability, 12(24), 10367. http://dx.doi.org/10.3390/su122410367.

Demuyakor, J. (2020). Coronavirus (COVID-19) and online learning in higher institutions of education: A survey of the perceptions of Ghanaian international students in China. Online Journal of Communication and Media Technologies, 10(3), e202018. https://doi.org/10.29333/ojcmt/8286.

Di Pietro, G., Biagi, F., Costa, P., Karpinski, Z., \& Mazza, J. (2020). The likely impact of COVID-19 on education: Reflections based on the existing literature and recent international datasets (No. JRC121071). Joint Research Centre (Seville site). http://dx.doi.org/10.2760/126686.

Erozkan, A. (2013). The effect of communication skills and interpersonal problem-solving skills on social selfefficacy. Educational Sciences: Theory and Practice, 13(2), 739-745. https://files.eric.ed.gov/fulltext/EJ1017303.pdf.

Garthwait, A. (2014). Pilot Program of Online Learning in Three Small High Schools: Considerations of Learning Styles. Electronic Journal of e-Learning, 12(4), 353-366. https://files.eric.ed.gov/fulltext/EJ1035685.pdf.

Gartmeier, M., Bauer, J., Fischer, M. R., Hoppe-Seyler, T., Karsten, G., Kiessling, C., ... \& Prenzel, M. (2015). Fostering professional communication skills of future physicians and teachers: effects of e-learning with video cases and role-play. Instructional Science, 43(4), 443-462. http://dx.doi.org/10.1007/s11251-0149341-6. 
Gulec, S., \& Temel, H. (2015). Body language using skills of teacher candidates from Departments of Mathematics Education and Social Studies Education. Procedia-Social and Behavioral Sciences, 186, 161-168. https://doi.org/10.1016/i.sbspro.2015.04.149.

Haider, S. I., \& Burfat, F. M. (2018). Improving Self-Esteem, Assertiveness and Communication Skills of Adolescents through Life Skills Based Education. Journal of Social Sciences \& Humanities (1994-7046), 26(2). http://issh.aiou.edu.pk/wp-content/uploads/2019/04/10-Syed-Imran-Haider.pdf.

Hodges, C., Moore, S., Lockee, B., Trust, T., \& Bond, A. (2020). The difference between emergency remote teaching and online learning. Educause Review, 27. https://er.educause.edu/articles/2020/3/the-differencebetween-emergency-remote-teaching-and-online-learning.

Isman, A., \& Dabaj, F. (2004). Communication barriers in distance education. In Society for Information Technology \& Teacher Education International Conference (pp. 491-496). Association for the Advancement of Computing in Education (AACE). https://www.learntechlib.org/primary/p/13517/.

Klapproth, F., Federkeil, L., Heinschke, F., \& Jungmann, T. (2020). Teachers' Experiences of Stress and Their Coping Strategies during COVID-19 Induced Distance Teaching. Journal of Pedagogical Research, 4(4), 444452. https://doi.org/10.33902/JPR.2020062805.

Kuban, C., \& Steele, W. (2011). Restoring safety and hope: From victim to survivor. Reclaiming Children and Youth, 20(1), 41. https://eric.ed.gov/?id=EJ932137.

Kwaah, C. Y., \& Essilfie, G. (2017). Stress and Coping Strategies among Distance Education Students at the University of Cape Coast, Ghana. Turkish Online Journal of Distance Education, 18(3), n3. https://files.eric.ed.gov/fulltext/EJ1147588.pdf.

Lawless, N., \& Allan, J. (2004). Understanding and reducing stress in collaborative e-learning. Electronic Journal of $\quad$ E-learning, 2(1),

121-127.

http://citeseerx.ist.psu.edu/viewdoc/download?doi=10.1.1.127.1925\&rep=rep1\&type=pdf.

Lazarus, R. S. (1993). From psychological stress to the emotions: A history of changing outlooks. Annual review of psychology, 44(1), 1-22. https://www.annualreviews.org/doi/pdf/10.1146/annurev.ps.44.020193.000245.

Mahmut, Ö. Z. E. R. (2020). Educational Policy Actions by the Ministry of National Education in the times of COVID-19 Pandemic in Turkey. Kastamonu Eğitim Dergisi, 28(3), 1124-1129. https://doi.org/10.24106/kefdergi.722280.

Manafa, I. F. (2018). Communication skills needed by principals for effective management of secondary schools in Anambra State. ONLINE JOURNAL OF ARTS, MANAGEMENT \& SOCIAL SCIENCES, 3(2). http://www.gojamss.net/journal/index.php/OJAMSS/article/view/374/373.

Mayende, G., Prinz, A., \& Isabwe, G. M. N. (2017). Improving Communication in Online Learning Systems. In CSEDU (1) (pp. 300-307). https://doi.org/229-236.10.5220/0006311103000307.

Ndidi, E. P., \& Alike, U. G. (2018). Principals' Application of Communication Skills as a Correlates of Teachers' Job Performance in Secondary Schools in Anambra State, Nigeria. Online Submission, 4(7),

Ogbo, R. N. P., Obiekwe, K. K., \& Emere, O. N. (2020). Assessing The Managerial Communication Skills Possessed By Principals For Administrative Effectiveness In Public Secondary Schools In Enugu State. GSJ, 8(6). https://files.eric.ed.gov/fulltext/ED586170.pdf.

Rayle, T. W. (2011). Principal perceptions about the implementation and effectiveness of online learning in public high schools in Indiana (Doctoral dissertation). http://scholars.indstate.edu/xmlui/bitstream/handle/10484/8080/Rayle,\%20Timothy.PDF?sequence=2.

Rehman, U., Shahnawaz, M. G., Khan, N. H., Kharshiing, K. D., Khursheed, M., Gupta, K., ... \& Uniyal, R. (2020). Depression, Anxiety and Stress Among Indians in Times of Covid-19 Lockdown. Community mental health journal, 1-7. https://dx.doi.org/10.1007\%2Fs10597-020-00664-x. 
Remland, M. S. (2016). Nonverbal communication in everyday life. Sage Publications.

Saadé, R. G., Kira, D., Mak, T., \& Nebebe, F. (2017). Anxiety \& Performance in Online Learning. In I n SITE 2017: Informing Science+ IT Education Conferences: Vietnam (pp. 147-157). https://www.informingscience.org/News.

Selye, H. (1950). Stress and the general adaptation syndrome. British medical journal, 1(4667), 1383. https://dx.doi.org/10.1136\%2Fbmj.1.4667.1383.

Shalian, J. (2021). Relationship between Teachers' Communication Skills and Students' Academic Well-being with Emphasis on the Mediating Role of Academic Adjustment in Girls' High Schools in Kashmar. Management and Educational Perspective, 3(1), 167-195. https://dx.doi.org/10.22034/imep.2021.282353.1056.

Siddiq, F., Scherer, R., \& Tondeur, J. (2016). Teachers' emphasis on developing students' digital information and communication skills (TEDDICS): A new construct in 21st century education. Computers \& Education, 92, 114. http://dx.doi.org/10.1016/j.compedu.2015.10.006.

Simonson, M., Zvacek, S. M., \& Smaldino, S. (2019). Teaching and Learning at a Distance: Foundations of Distance Education 7th Edition. IAP.

Simsek, S., \& Erdem, A. R. (2020). Corelation between Communication Skills and Motivation of Teachers. International Online Journal of Educational Sciences, 12(3), 1-9. https://iojes.net/?mod=makale ing ozet\&makale id=42633.

Sprang, G., \& Silman, M. (2013). Posttraumatic stress disorder in parents and youth after health-related disasters. Disaster medicine and public health preparedness, 7(1), 105-110. https://doi.org/10.1017/dmp.2013.22.

Syaiful, S., Muslim, M., Huda, N., Mukminin, A., \& Habibi, A. (2019). Communication skills and mathematical problem solving ability among junior high schools students through problem-based learning. International Journal of Scientific \& Technology Research, 8(11). https://repository.unja.ac.id/12269/3/Turnitin Communication\%20Skills\%20And\%20Mathematical\%20Prob lem\%20Solving\%20Ability\%20Among\%20Junior\%20High\%20Schools\%20Students\%20Through\%20ProblemBased\%20Learning\%20\%283\%29.pdf.

Toppo, T., \& Philomina, M. J. (2021). A Study on the Problems in Communication Skills Faced by the Teachers in the Secondary Schools of Namsai District in Arunachal Pradesh. INFORMATION TECHNOLOGY IN INDUSTRY, 9(3), 42-50. file:///C:/Users/User1/Desktop/481-Article\%20Text-868-2-10-20210419.pdf.

United Nations (2020). Education during COVID-19 and beyond, Policy Brief, United Nations, available at: https://www.un.org/development/desa/dspd/wpcontent/uploads/sites/22/2020/08/sg policy brief covid-19 and education august 2020.pdf.

Zaidi, A. H., Nadeem, M., \& Gill, A. R. (2019). Comparative Study of Stress and Anxiety in Learning of Foreign Languages (Arabic and English) at Elementary School Level in Punjab. Pakistan Journal of Social Sciences (PJSS), 39(2), 513-521. https://media.teckiz.com/pakistan-journal-of-social-sciences/pjssbzu/2020/05/29/5ed10fc175e1c.pdf. 